\title{
PREPARING THE GROUND FOR MARINE SPATIAL PLANNING IN IRELAND
}

\author{
W. FLANNERY ${ }^{1}$, E. NIXON ${ }^{2}$ \& M. Ó CINNÉIDE ${ }^{1}$ \\ ${ }^{1}$ Department of Geography, National University of Ireland, Galway, Ireland. \\ ${ }^{2}$ Marine Institute, Dublin, Ireland.
}

\begin{abstract}
Marine spatial planning (MSP) is advocated as a means of managing human uses of the sea in a manner that is consistent with the maintenance of the ecological goods and services of the marine environment. The adoption of a system of MSP is seen as urgent in the face of ever-increasing demands on marine resources. This is particularly so in Ireland with its extensive seas, belatedly being recognised as a significant development resource. MSP is promoted by the European Commission (EC) in a recent Green Paper to which Member States of the Union, including Ireland, generally have responded positively. Arising from this consultative process, the EC has published the 'Blue Book' that commits support for MSP. It has also issued guidelines for an integrated approach to maritime policy. The recently adopted EU Marine Strategy Framework Directive strengthens the case for implementing MSP as it requires each Member State to develop a strategy for its marine resources. There is evidence that a diverse range of stakeholders at national and local levels in Ireland are positively disposed toward MSP but no practical manifestation of the concept is in place, though some preparatory work is underway to facilitate its likely implementation into the future.

Keywords: integrated maritime governance, Ireland, marine resources, marine spatial planning.
\end{abstract}

\section{INTRODUCTION}

This paper begins by briefly outlining the importance of the marine sector to the Irish economy. The paper illustrates how the marine environment is managed on a sectoral basis by central government and highlights the lack of a coherent marine policy in Ireland. It then describes various international drivers of marine spatial planning (MSP) which promote integrated management practices of marine resources. MSP requires baseline scientific data as well as stakeholder support for the process. A synthesis of two stakeholder surveys that reveal support for MSP is presented. The paper then outlines some scientific research being undertaken in the Irish marine environment in support of MSP. Recommendations relating to an integrated approach to maritime governance and an associated system of MSP are advanced.

\section{IRELAND'S MARINE RESOURCE}

Ireland is a small island economy with an extensive marine resource (Fig. 1). It consists of 90,000 $\mathrm{km}^{2}$ of land resource and almost $900,000 \mathrm{~km}^{2}$ of marine resource [1]. The marine sector directly employs approximately 22,000 people and provides indirect employment for another 22,000. It generates a turnover of nearly $€ 3$ billion (Table 1), contributing approximately $1 \%$ of Ireland's gross national product (GNP). This is a considerably lower percentage than in most other maritime countries: the marine sector is estimated to contribute 3.5-4.9\% of the UK's GNP, with a turnover of $€ 23.7$ billion [1]. On a comparative basis, Ireland's marine resource is underutilised and underdeveloped. However, GNP is a crude gauge of its significance and conceals the importance of the marine sector to Ireland as an island nation on the edge of Europe [2]. Over $99 \%$ of Ireland's exports and imports, for example, are carried by shipping, while an estimated 4 million people travel to and from Ireland each year on international ferries [2].

Although Ireland's maritime economy is very much dependent on policy coherence and the establishment of a legal framework that provides for continuity, clarity and certainty, currently it does not

(C) 2010 WIT Press, www.witpress.com

ISSN: 1743-7601 (paper format), ISSN: 1743-761X (online), http://journals.witpress.com DOI: $10.2495 /$ SDP-V5-N1-57-67 


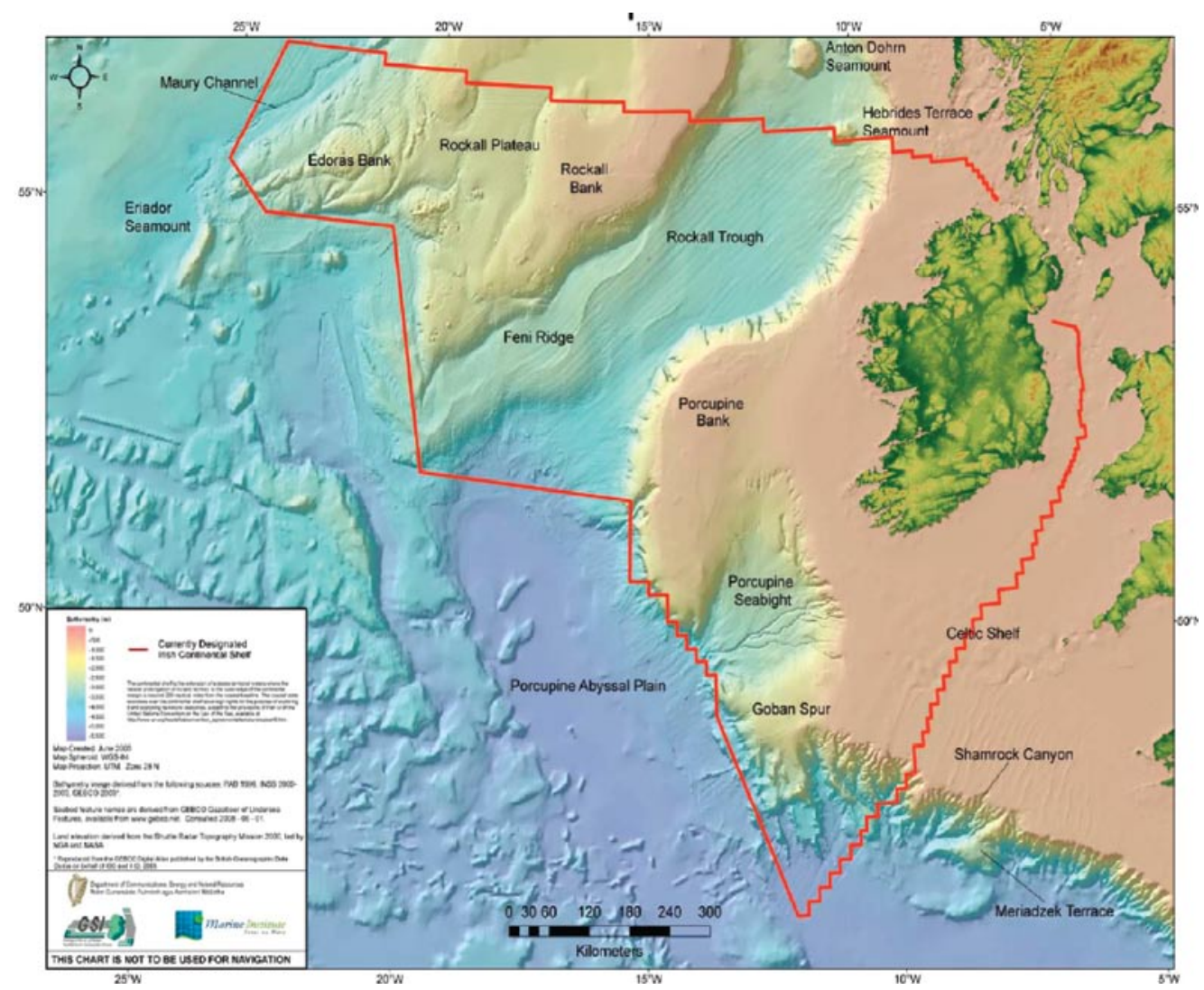

Figure 1: Irish continental shelf. Source: Department of Communications, Energy and Natural Resources, Geological Survey of Ireland and The Marine Institute.

Table 1: Value of marine sector to Irish economy. Source: Marine Institute, [1].

\begin{tabular}{lc}
\hline Marine sector & Value to Irish economy \\
\hline Shipping \& Maritime Transport & $€ 1,275$ million \\
Water Based Tourism & $€ 566$ million \\
International cruise liners & $€ 66$ million \\
Other marine services & $€ 121$ million \\
Fish landings & $€ 210$ million \\
Fish processing & $€ 366$ million \\
Hydrocarbon exploration & $€ 22$ million \\
Offshore renewable energy & $€ 18$ million \\
Seaweed & $€ \quad 9$ million \\
Aquaculture & $€ 110$ million \\
Offshore oil and gas & $€ 115$ million \\
Marine technology & $€ 69$ million \\
Boat building & $€ 20$ million \\
Other marine manufacturing & $€ 116$ million \\
Total value & $€ 3,001$ million \\
\hline
\end{tabular}


have an over-arching national marine policy [2]. Planning in respect of the marine environment in Ireland is pursued by a variety of bodies, which makes it difficult for a holistic, integrated approach to prevail. During the 1980s, there were several public bodies responsible for formulating marine policy in Ireland. A number of overlapping competencies were identified and it became clear that the development of the marine sector was being hindered by poor planning structures and by a lack of a coordinated marine policy [2]. This led to the formation of the Department of Marine in 1987, which was to coordinate government policy on maritime affairs. The Department placed significant emphasis on the principle of sustainable development [2].

In 1997, a strategy document, Coastal Zone Management: A Draft Policy for Ireland, highlighted the multipart and sectoral nature of Ireland's legislative and administrative framework in the coastal zone and advocated the implementation of integrated coastal zone management (ICZM) as a means of integrating them [3]. Even though there have been statements supporting the use of ICZM as a management tool within subsequent government strategies, including the National Spatial Strategy, there has been little progress toward its deployment in policy or legislative developments since the publication of the draft policy [4].

Government departmental structures in Ireland are evolving and continually changing over recent times. The Department of the Marine and Natural Resources, as it was known previously, became part of the larger Department of Communications, Marine and Natural Resources in 2002 [2]. This department later became the Department of Communications, Energy and Natural Resources, with competencies for marine matters being redistributed among various departments and agencies. At the time of writing, the administration of marine-related functions is being apportioned between four different government departments having responsibilities as follows: fisheries and aquaculture (Department of Agriculture, Fisheries and Food); foreshore activities and conservation (Department of the Environment, Heritage and local Government); fossil and renewable energies (Department of Communications, Energy and Natural Resources); and transports and ports (Department of Transport).

With respect to development planning and control in the foreshore, the jurisdiction of local planning authorities extends only to the mean high water mark. There is ambiguity over this boundary as it is based, in part, on outdated data. This compounds the issue of split jurisdiction between terrestrial and marine authorities [2]. However, the Planning and Development Act, 2000 increased local authorities' powers in relation to foreshore planning and development by providing them with a legislative basis to include objectives regarding development on the foreshore in their development plans [2].

\section{DRIVERS OF MSP}

MSP is advocated as a means of managing human uses of the sea in a manner that is consistent with the maintenance of the ecological goods and services of the marine environment. An integrated approach to maritime policy and the implementation of a system of MSP are seen by many, including the European Commission (EC) (Blue Book), UNESCO (Workshop Report), Irish Government (Maritime Policy Consultation Process: Irish response) and the (Irish) Marine Institute (Sea Change), as an imperative, especially due to ever-increasing demands on the marine resource.

MSP is also considered to be a key tool for the sustainable management of activities within the EU-wide network of nature protection areas established under the 1992 Habitats Directive. It is comprised of Special Areas of Conservation designated by Member States under the Habitats Directive, and also incorporates Special Protection Areas which were designated under the 1979 Birds Directive. The aim of the network is to assure the long-term survival of Europe's most valuable and threatened species and habitats, with an emphasis on ensuring that future management is sustainable, both ecologically and economically (http://ec.europa.eu/environment/nature/natura2000/index_en.htm). 
The Irish government has failed to apply these Directives in the correct manner and has been subject to enforcement proceedings taken by the EC [2].

The EC Water Framework Directive requires Member States to deliver a statutory framework to achieve good ecological status in transitional, estuarine and coastal waters, as well as internal river basins [5]. This process necessitates an integrated assessment of ecological stresses on water bodies, with the eventual goal of achieving good ecological and chemical status by 2015. Member States are obliged to construct a register of protected areas and develop a management strategy for each river basin. MSP is considered to be a process through which Member States could achieve the EU recommendations on ICZM. In 2002, the first High-Level Forum on ICZM highlighted the potential to use spatial planning, in conjunction with sea-use planning and marine resource management, as a method of implementing ICZM [6]. Contracting parties to the 1992 OSPAR Convention, including Ireland, have agreed to employ the ecosystem approach in the management of their marine ecosystems. Contracting Parties also have agreed to implement this approach through the application of the Malawi Principles [7]. These Principles consider the ecosystem to be the primary management unit and state that management should be decentralised to the lowest appropriate level, should include indigenous and local knowledge, innovations and practices, and should include all relevant sectors of society [7].

The EC is a key advocate of MSP. The EC launched a Green Paper on the Future Maritime Policy for the European Oceans and Seas in June 2006 [8]. The Irish government, in its response to the Green Paper, supported the Commission's objective of attaining good status of the EU's marine environment by 2021, which would be underpinned by implementing the ecosystem approach to MSP [9]. The recently adopted EU Marine Strategy Framework Directive strengthens the case for implementing MSP as it requires each Member State to develop a marine strategy for its marine waters, which, while being specific to its own waters, reflects the overall perspective of the marine region or sub-region concerned [10]. The EC has also issued guidelines for integrated governance frameworks for Europe's seas and oceans in order to encourage Member States to prepare national integrated maritime policies, in close collaboration with their maritime stakeholders and to enhance and facilitate cooperation at all levels of maritime governance, including at the European level [11]. Through this communication from the EC, Member States are urged to consider creating internal coordinating structures for maritime affairs within their government frameworks. International levels of decision-making are regarded as having a role to play, and active participation by maritime stakeholders in formulating integrated national, regional and local maritime policies is highly recommended.

Ireland has also signed up to Agenda 21, which, under chapter 17, commits the State to the integrated management and sustainable development of the coastal zone, including its exclusive economic zone. This requires the implementation of new integrated approaches to marine and coastal management. Chapter 28 of Agenda 21 recognises that many of the problems and solutions being addressed by Agenda 21 have their foundation in local activities. Therefore, the participation and cooperation of local authorities are regarded as crucial in fulfilling related objectives [12]. In order to achieve these objectives, local authorities are to enter into discussions with citizens, local organisations and private enterprises. Through a process of consultation and consensus building, it is thought that they will acquire the information needed for formulating the best management strategies [12]. Thus, Agenda 21 is not only a driver of MSP, but also advances the case for local stakeholder participation in the production of marine spatial plans.

The adoption of an integrated approach to the management of the marine environment appears to have been successful in the case of the leading maritime nations, including Canada and the Netherlands. In 1996, Canada enacted the Canada Oceans Act. This led to Canada's Ocean Strategy, Our Oceans, Our Future (2002), which is a policy statement for the management of estuarine, coastal and marine ecosystems guided by the principles of sustainable development, the precautionary 
approach and integrated management. Initial progress under this strategy was slow due to a lack of funding, resources and capacity; inter-agency conflict; and institutional distrust [13]. Significant progress has been made with integrated management initiatives established by the Ocean Action Plan (2005), the Eastern Scotian Shelf Integrated Management Initiative (ESSIM) being a case in point. A government level committee, The Regional Committee on Ocean Management, was created to integrate and harmonize policies and actions, and to incorporate the objectives and measures of the ocean management plan into existing planning and decision-making processes for all ocean sectors [14]. A multi-stakeholder group, The Ocean Management and Planning Group, functions as the core of the ESSIM Forum to provide objective and inclusive opportunities for ongoing communications, information sharing and advice for integrated management and planning [14]. In 2005, the Netherlands published An Integrated Management Plan for the North Sea 2015. As part of the management strategy, central government organisations with competencies for the North Sea became part of the North Sea Management Network, which is coordinated by the North Sea Department of the Directorate General for Public Works and Water Management. The North Sea Management Network's main tasks are enhancing knowledge and information management, thus reducing the burden for users [15]. Other countries that have initiated MSP projects include Australia, Belgium, Finland, Germany, Norway, the United Kingdom and the United States. While these initiatives need further evaluation, including from a participation and governance perspective, it is clear that the process of constructing plans initiates the necessary steps towards integration and coordination of departments and agencies, and the participation of interests groups. As the ESSIM Initiative in Canada illustrates, time is needed to coordinate the various agencies and departments, to harmonise sectoral regulations, build stakeholder capacity and trust in the process, and for consensus building.

A system of MSP represents a valuable planning tool for those charged with managing the marine environment. Historically, this environment has been managed in an uncoordinated fashion as coastal states generally pursued sectoral approaches to regulate access to marine resources. These approaches have created areas of expertise for particular activities or resources but have resulted in a segmented view of the marine ecosystem being developed and enshrined in policy [16]. Due to this, a clear understanding of the ways in which human activities interact with each other and their cumulative impact on the marine environment are lacking. By concentrating on the distinctive characteristics of individual places, MSP allows management regimes to be designed for a certain set of conditions [17]. This facilitates better monitoring, enhances the understanding of the cumulative impact human activity has on the marine ecosystem and enables managers to take timely action to minimize the risk of ecosystem collapse [17]. A system of MSP has the potential, among other things, to improve the consistency and compatibility of regulatory decisions, increase governments' capacity to deliver sustainable development in the marine environment, afford greater clarity of policy and decisionmaking, reduce conflict between stakeholders and increase public participation in the planning process [16]. It also gives a higher degree of certainty to developers and decision makers alike, by providing clear indications of where particular projects are likely to be approved or rejected.

\section{STAKEHOLDER SUPPORT FOR A PROCESS OF MSP IN IRELAND}

Stakeholder participation and involvement are integral to the success of MSP [18]. Collaborative planning processes have achieved acceptance in spatial planning as they offer the opportunity of reconciling the concerns of diverse stakeholders and of building local institutional capacity [19]. Recently, the use of the 'bottom-up' approach to environmental management initiatives has increased due to the perceived failings of the 'top-down' approach [20]. The collaborative planning process is seen as a learning and iterative process where participants learn about the nature and trustworthiness of other stakeholders and grow to recognize the legitimacy of each other's viewpoints [21]. 
At national level in Ireland, commitment to terrestrial spatial planning is evidenced by the recent preparation of a National Spatial Strategy in 2002. The preparation of development plans by municipal level planning authorities represents practical manifestations of spatial planning at the local geographic scale. There is no corresponding spatial planning process in respect of the marine environment. However, two recent studies of national level and local level stakeholders, respectively, indicate support for a process of MSP. As there is no immediately identifiable group, body or constituency at national level where considered views pertaining to MSP may be canvassed, the national level study concentrated on professional administrators and their scientific and resource management advisors to evaluate 'high level' stakeholders' perceptions of MSP [22]. The survey focused on full-time professionals employed by environmental and industrial representative bodies, nongovernmental organisations, as well as experienced independent consultants involved in marine related matters. In addition, views were sought from a number of terrestrial land use planners. Of the $41 \mathrm{com}-$ pleted questionnaires considered in this study, 26 described themselves as being from the state sector (including one from the education sector), 9 from industry, 3 NGOs and 3 consultants [22].

Asked if MSP should be implemented in Ireland, 100\% of the respondents replied positively, although some entered caveats. These centred on issues of commitment, political will, coastal development and the need for assurances that MSP would be undertaken properly. About $97 \%$ of the respondents were in favour of MSP being implemented as a statutory framework for decision-making. The state sector is probably the most experienced in the intricacies of current decision-making processes relating to the marine environment in Ireland, and this level of support from survey respondents drawn predominately from the state sector is a strong indication of a perceived need for change to the current system. Thirty-three respondents supported the idea of seeking consensus among stakeholders. One respondent from the aquaculture and seaweed industrial sector, who was opposed to this idea, replied that there was a need to define 'interested parties' and was of the view that only those with a social or economic interest should be consulted in the planning process. Another respondent from the state terrestrial planning sector was of the opinion that 'plans should be prepared in consultation with interested parties, but should be adopted by a statutory body with democratic representation so that it can be binding (i.e. should be more akin to a development plan as prepared by planning authorities than a strategy or guidelines)'. A respondent from the state environmental protection sector suggested that 'while consensus is rarely achievable, the engagement of coastal communities through inclusion of stakeholders' views in the process would be beneficial'. All NGOs consulted were in favour of finding consensus among interested parties. Respondents' views on the most appropriate lead agency to implement MSP in Ireland are summarised in Table 2. The largest number of respondents (48\%) favoured the establishment of a new marine agency, $26 \%$

Table 2: High-level stakeholder opinions on lead agency. Source: adapted from Nixon, [22].

\begin{tabular}{lcc}
\hline Lead agency & Number of respondents & \% of respondents \\
\hline Government department & 11 & 27 \\
Regional authorities & 3 & 7 \\
Local authorities & 2 & 5 \\
Marine Institute & 1 & 2 \\
New Marine Agency & 20 & 49 \\
A mix of national and local authorities & 2 & 5 \\
Umbrella Group & 2 & 5 \\
Total & 41 & 100 \\
\hline
\end{tabular}


were in favour of it being implemented by an existing government department. Fewer than 5\% were in favour of it being implemented by local planning authorities.

The second study, targeting local-level stakeholders in the marine environment, was conducted in the Dingle Peninsula, on the south-west coast of Ireland. A total of 95 questionnaires were completed. A purposeful sampling technique was utilised as it allowed for the deliberate selection of people with specific characteristics, behaviour or experience, in this case people whose livelihoods are directly or indirectly derived from the sea and other active users of the marine environment [23]. Strong support for MSP was apparent among these stakeholders. About $91 \%$ of fishers interviewed were in favour, though some added that their support for it would depend on the manner in which it was to be implemented. Reasons given for supporting MSP included: the opportunity it would give fishers to diversify; a means to curb pollution; a way of coordinating marine development; it would create greater clarity about what will happen in the area in the future; it would help reduce user conflict, as well as controlling and optimising resource use; and would help facilitate sustainable development, e.g. by creating special areas for conservation; it would also help promote new marinebased economic activities, e.g. by designating areas for recreation and by facilitating the exploitation of renewable energy sources [23]. Some reservations expressed included: it could promote effective private ownership of specific sea areas; consensus would be hard to achieve; it would be opposed by some local stakeholders; it would descend into a local political quagmire; it could create no-go or no-take areas; much would depend on who created the plan; it would favour economic interests; it would be difficult to get stakeholders to abide by the plan; and the process could be taken over by dominant local groups [23].

Two different approaches to implement MSP were investigated in this study: (a) from the topdown by a national agency but with inbuilt local participation and (b) from the bottom-up by local stakeholders with outside expertise, datasets, etc., as considered necessary. The latter option was strongly favoured with some $70 \%$ of respondents opting for this approach [23]. One respondent, who was employed in marine management, emphasised that MSP should be implemented by a national agency. In the recent past, this respondent had previously participated in an ICZM scoping exercise for the area. The respondent argued that a great deal of expertise was required to plan the marine environment and even if this expertise was available to stakeholders, as part of a locally led planning process, there was a need to have a national agency oversee the process in order for it to be free from local pressures and base decisions on objective scientific criteria [23]. Other arguments offered in favour of the 'top-down' planning process included: plans would need to be integrated with other local, regional, and national plans; it would afford a wider perspective of how the marine environment should develop; it would be free from local political considerations; and there was a strong probability that it would place due emphasis on conservation [23]. Local economic interests, including fishing, aquaculture, and providers of water-based tourism and leisure activities, strongly favoured a locally led implementation process. The arguments offered in support of a locally led approach included: a possibility that it would benefit the local community; local participation would maximise local influence and control over the process; capacity would be enhanced through active participation; fishers would have more of a voice in this process which was justified by their vital stakeholding in the marine environment; and it would ensure that the character of the area was preserved [23]. Respondents' views regarding the lead agency to implement MSP were also solicited (Table 3). A somewhat unclear and partly contradictory picture emerged with $32 \%$ of respondents articulating support for the establishment of a new government agency to oversee the implementation of MSP and a local area based partnership being preferred by $22 \%$. Some support was evident for existing national and regional bodies including Bord Iascaigh Mhara (the Irish Fisheries Board), Údarás na Gaeltachta (a regional development agency), the Marine Institute (national agency 
Table 3: Local-level stakeholder opinion on lead agency.

\begin{tabular}{lcc}
\hline Lead agency & Number of respondents & $\%$ of respondents \\
\hline Department of Agriculture, Fisheries and Food & 6 & 6 \\
Department of Communications, Energy & 9 & 9 \\
and Natural Resources & 8 & 8 \\
Department of Environment and Local Government & 4 & 5 \\
Other government department & 7 & 7 \\
The Marine Institute & 30 & 32 \\
A new government agency specifically & 22 & 23 \\
for this purpose & 1 & 1 \\
A local area partnership & 8 & 8 \\
Local authority & 95 & 100 \\
Other & & \\
Total & & \\
\hline
\end{tabular}

responsible for marine research, technology, development and innovation) and various government departments with competencies related to the marine environment. Support for the local planning authority as lead agency was weak, with only one respondent advancing this option [23].

\section{SCIENTIFIC RESEARCH}

MSP requires detailed geophysical and biological data regarding the nature of the seabed [1]. The EU Green Paper emphasises that the mapping of coastal waters is a prerequisite for effective MSP. Seabed mapping provides the information necessary to spatially define many seabed resources and boundaries and to identify potential opportunities and constraints (Fig. 2 shows the extent of the Burford Bank, a potentially important sand deposit in the Irish Sea, close to Dublin). It is anticipated that the maps constructed from these projects will assist decision-makers implement sustainable development strategies through an integrated system of MSP.

Ireland is ahead of other European Countries in this regard, as it has completed an extensive seabed survey and is in the process of completing a detailed inshore mapping project [2]. The Geological Survey of Ireland and the Marine Institute are the lead agencies overseeing these projects. Between 1999 and 2005, the Irish National Seabed Survey mapped over 85\% of the Irish marine continental shelf. For the purpose of the survey, the seabed was divided into three zones: $0-50 \mathrm{~m}$ isobaths, 50-200 m isobaths and 200-4,500 m isobaths [2]. INFOMAR (the Integrated Mapping for the Sustainable Development of Ireland's Marine Resource), representing phase two of this project, runs from 2007 to 2010 and is focused on the coastal zone. Initially, INFOMAR is focusing on 26 bays and 3 priority areas (Fig. 3). These were identified during an extensive stakeholder exercise that was conducted between 2002 and 2005. This exercise included consultation with over 50 organisations, including government departments, coastal local authorities, industry sectors and consultancy companies. During this period, the EU designated Biologically Sensitive Area was also surveyed on an opportunistic basis.

\section{CONCLUSIONS}

Marine policy in Ireland is determined at government level with some input from industry but with little consultation with the general public or wider interests. A key lesson from international experience 


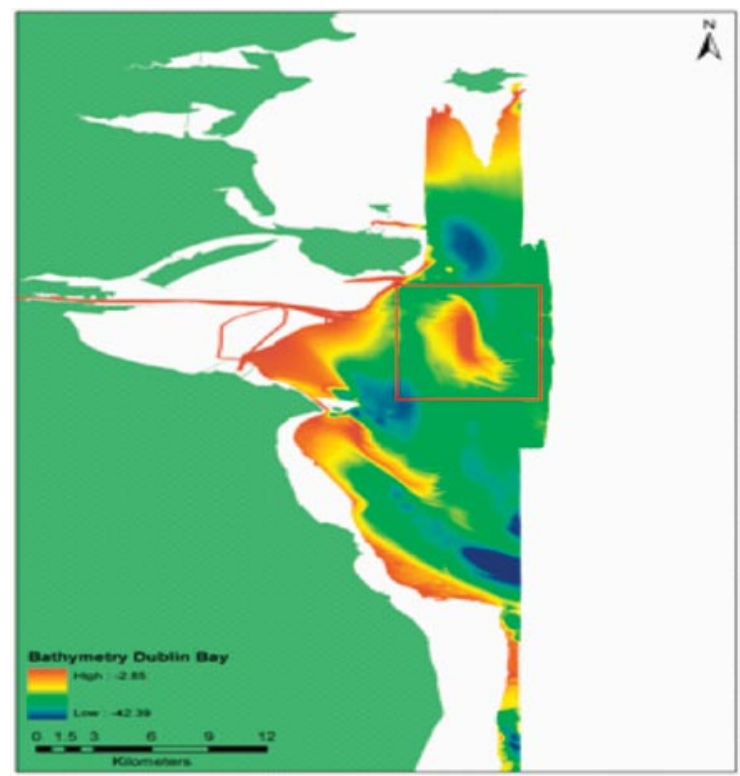

Figure 2: The limits of the Burford Bank. Source: INFOMAR.

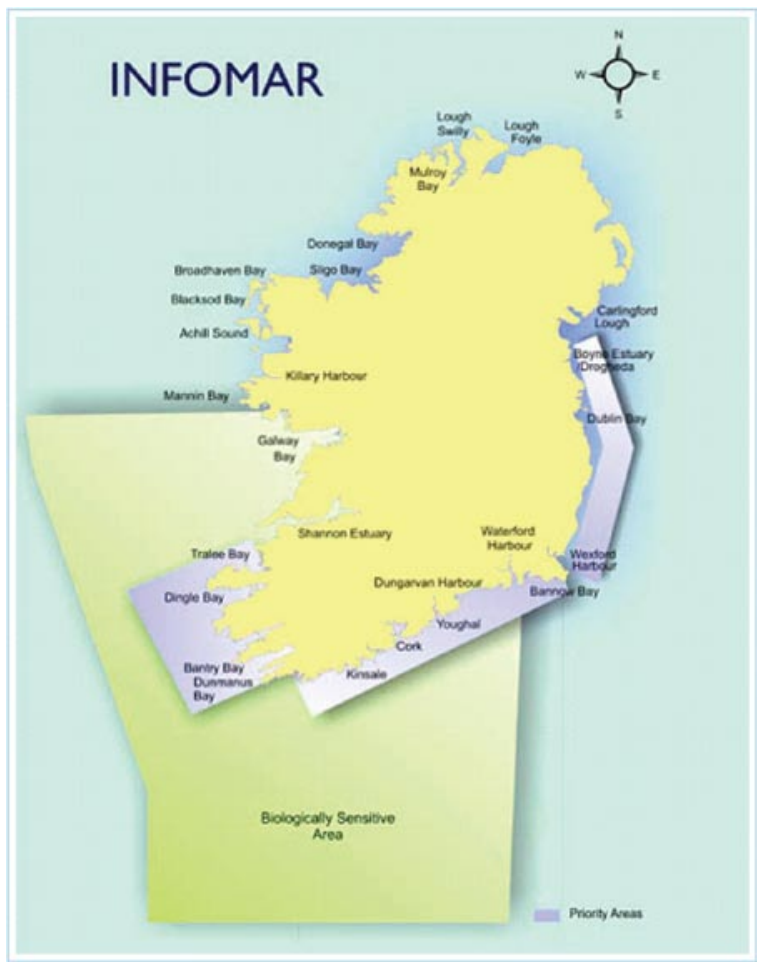

Figure 3: Location of 26 priority bays, three priority areas and the Biological Sensitive Area designated under the EU's Common Fisheries Policy. Source: INFOMAR. 
is that marine policy receives its legitimacy from the public and is successful only if it concentrates on delivering tangible outcomes that have public support [2]. MSP is viewed as a management tool with the potential to contribute to policy coherence, help establish a collaborative framework that would help legitimise marine policy through public participation, and bring clarity and certainty to development in the marine environment. MSP is strongly advocated by various international bodies, including the EC, and is already being implemented by leading maritime nations.

The evidence from the stakeholder surveys conducted in Ireland demonstrates support for a system of MSP involving meaningful local involvement. There is strong support at a local level for a bottom-up process, though the need for top-down steering and guidance is also recognised. An approach which would see local level plans nested within larger area plans with both having regard to nationally set objectives is suggested as a suitable framework. A new national agency to lead MSP is desired by many local and national stakeholders. Failing this, a single department with responsibility for preparing marine spatial plans and overseeing their implementation is essential. This is particularly true due to the fragmentation of responsibilities relating to marine governance into a number of different government departments.

If MSP is to be put on the agenda in Ireland, it will need political and administrative support. Without political leadership, the concept will have little chance of being implemented [22]. Political leadership is required in the development of a national consensus relating to an integrated marine policy. This will require the development of mechanisms through which the public can engage in debate about the management of our marine resources [2]. A MSP framework is such a mechanism. The stakeholder studies outlined above demonstrate that there is a willingness to engage in such a process. Having already developed some of the necessary datasets to engage in MSP, it is now paramount that the outputs of marine-related research are exploited to support and inform policy development. In this regard, experiences of good practice from other jurisdictions as well as from terrestrial spatial planning must be utilised.

\section{REFERENCES}

[1] Shields, Y., O'Connor, J. \& O'Leary, J., Ireland's Ocean Economy \& Resources, Marine Foresight Series No. 4, Marine Institute, Galway, 2005.

[2] Long, R., Marine Resource Law, Thompson Round Hall: Dublin, 2007.

[3] Brady Shipman Martin, Coastal Zone Management: A Draft Policy for Ireland, Department of the Marine and Natural Resources, Dublin, 1997.

[4] Cummins, V., O Mahony, C. \& Connolly, N., Review of Integrated Coastal Zone Management and Principles of Best Practice, The Heritage Council, Coastal and Marine Resources Centre, Ireland, 2004.

[5] EC, Directive 2000/60/EC of the European Parliament and of the Council of 23 October 2000 establishing a framework for Community action in the field of water policy. Official Journal of the European Communities, L327, pp. 1-73, 2000.

[6] MSSP Consortium, Marine Spatial Planning: Literature Review, DEFRA: London, 2005.

[7] Garcia, S.M., Zerbi, A., Aliaume, C., Chi, T. \& Lasserre, G., The ecosystem approach to fisheries: issues, terminology, principles, institutional foundations, implementation and outlook. FAO Fisheries Technical Paper 443, FAO, Rome, 2003.

[8] EC, Towards a Future Maritime Policy for the Union: A European Vision for the Oceans and Seas, Commission of the European Communities Com (2006) 275 final, Commission of the European Communities, Brussels, 2006.

[9] Government of Ireland, Irish Response to the EU Maritime Green Paper Towards a Future Maritime Policy for the Union, Government of Ireland, Dublin, 2007. 
[10] EC, Directive 2008/56/EC of the European Parliament and of the Council of 17 June 2009 Establishing a Framework for Community Action in the Field of Marine Environmental Policy (Marine Strategy Framework Directive), Commission of the European Communities, Brussels, 2008.

[11] EC, Guidelines for an Integrated Approach to Maritime Policy: Towards Best Practice in Integrated Maritime Governance and Stakeholder Consultation, Commission of the European Communities, Brussels, 2008.

[12] UNCED, Agenda 21-United Nations Conference on Environment and Development: Outcomes of the Conference, Rio de Janeiro, Brazil, 1992.

[13] Guenette, S. \& Alder, J., Lessons from marine protected areas and integrated ocean management initiatives in Canada. Coastal Management, 35, pp. 51-78, 2007.

[14] Rutherford, R.J., Herbert, G.J. \& Coffen-Smout, S.S., Integrated ocean management and the collaborative planning process: the Eastern Scotian Shelf Integrated Management (ESSIM) Initiative. Marine Policy, 29, pp. 75-83, 2005.

[15] IDON, Integrated Management Plan for the North Sea 2015, Interdepartmental Directors' Consultative Committee, North Sea, Rijswijk, 2005.

[16] Tyldesley, D., Irish Sea Pilot Project: Coastal and Marine Spatial Planning Framework. Report to the Joint Nature Conservation Committee, Defra, London, 2004.

[17] Young, O.R., Osherenko, G., Ekstrom, J., Crowder, L.B., Ogden, J., Wilson, J.A., Day, J.C., Douvere, F., Ehler, C.N., McLeod, K.L., Halpern, B.S. \& Peach, R., Solving the crisis in ocean governance: Place-based management of marine ecosystems. Environment, 49, pp. 20-32, 2007.

[18] Pomeroy, R. \& Douvere, F., The engagement of stakeholders in the marine spatial planning process. Marine Policy, 32, pp. 816-822, 2008. doi:10.1016/j.marpol.2008.03.017

[19] Healey, P., Collaborative Planning: Shaping Places in Fragmented Societies, Palgrave Macmillan: Basingstoke, 2006.

[20] Fraser, E.D.G., Dougill, A.J., Mabee, W.E., Reed, M. \& McAlpine, P., Bottom up and top down: analysis of participatory processes for sustainability indicator identification as a pathway to community empowerment and sustainable environmental management. Journal of Environmental Management, 78, pp. 114-127, 2006. doi:10.1016/j.jenvman.2005.04.009

[21] Keen, M. \& Mahanty, S., Learning in sustainable natural resource management: challenges and opportunities in the Pacific. Society \& Natural Resources, 19, pp. 497-513, 2006. doi:10.1080/08941920600663896

[22] Nixon, E., Marine Spatial Planning for Ireland: Potential Benefits and Barriers (unpublished thesis), Dublin Institute of Technology, Dublin, 2006.

[23] Flannery, W. \& Ó Cinnéide, M., Marine spatial planning from the perspective of a small seaside community in Ireland. Marine Policy, 32, pp. 980-987, 2008. doi:10.1016/j. marpol.2008.02.001 